\title{
Android-based Dental Anatomy Learning Application Using Mayer's Multimedia Learning Principles
}

\author{
Deka Desilawati ${ }^{1}$, Haris Setyawan ${ }^{1 *}$ and Reza Giga Isnanda ${ }^{1}$ \\ ${ }^{1}$ Universitas Muhammadiyah Yogyakarta, Jln.Brawijaya, Tamantirto, Kasihan, Bantul, Yogyakarta 55183, \\ Indonesia \\ *Corresponding author: haris.setyawan@umy.ac.id
}

\begin{abstract}
Anatomy learning methods are still dominated by using books, in which the material is presented in pictures and writings. The anatomy learning method using books is carried out by redrawing parts and memorizing the location and its terms. Thus, students have difficulties when they forget and want to find terms on the anatomy because it is uneasy and takes a long time. This research aims to create a system to study anatomy, especially dental anatomy, through an android-based application, and provide ease of anatomy of tooth learning using Mayer's principle of multimedia learning on application. Based on system testing and user testing results, this application can be used as a medium of information and learning about tooth anatomy. It is evidenced by black-box testing and questionnaire results.
\end{abstract}

Keywords: Dental Anatomy, Educational Application

\section{Introduction}

Anatomy comes from the Greek ana and tome, meaning to cut or separate. Anatomy is the study of human body structures and the relationships between one part and another[1]. From a medical perspective, anatomy consists of various knowledge about the shape, location, size, and various human body structures.

Most anatomy learning is performed using books, with the material presented in pictures and writings. This method is conducted by redrawing each section and memorizing the location and terms. It makes it difficult for students to forget and look for terms in the book's anatomy section because it is uneasy and takes a long time. Some students may have different ways to prevent it, such as coloring the writings or pictures using a highlighter or marking the page. However, most students are lazy to do so.

Several solutions are offered to facilitate anatomy learning; an example is the creation of a smartphone application dealing specifically with anatomies such as the circulatory system, the respiratory system and others. However, the application offered is still unable to be used as a learning method using multimedia because they were made similar to the book, thus requiring application development.

According to Mayer[2], multimedia is a material presentation using words and pictures. Words are presented in written or spoken forms, and images can be presented in static or dynamic graphics. In his book, Mayer mentions that 12 multimedia learning principles can be applied in learning methods using multimedia.

Learning application of human circulatory system based on android can be built using Eclipse. This provides material about the human circulatory system that is intended for junior high school students. This application aims to help students be more accessible in learning biological materials, especially in the fabric of the human circulatory system[3].

In the research application of human body anatomy learning with a clipping method based on android can be used for medical students to be implemented to android-based mobile 
devices by cutting images. This android-based human body anatomy was a learning app to discuss the blood vessels, respiratory tract, and gastroint estinal tract[4].

Denature journal that discusses the application of mobile learning anatomy of the human body based on android can display human body organs with categories of the respiratory system and sensory system. The respiratory system application program contains material in which the user selects the respiratory system's type comprising an explanatory image of the material[5].

Currently, there are only a few dental anatomy apps available on the play store. It encourages researchers to create and develop an Android-based dental anatomy application as a multimedia learning method that can be used as an alternative medium for studying dental anatomy. The application was created using several Mayer Multimedia Learning principles, such as the Coherence Principle, Spatial Contiguity Pricing, and Multimedia Principle. Using these three multimedia learning principles, the authors present the dental anatomy material in images and text simultaneously and sort out the necessary and unnecessary material.

Therefore, the researchers tried to develop an application as a means of learning to study human anatomy based on Android mobile. This project was then made with the title "Android-based Dental Anatomy Learning Application Using Mayer Multimedia Learning Principles”.

\section{Method}

Application development in this research utilized the waterfall model System Development Life Cycle (SDLC) method. This waterfall model comprises six stages: architectural planning, needs analysis, designing using UML, application development, testing, and implementation. The dental anatomy learning application concept is that users can easily learn anatomy and practice using a smartphone. Dental anatomy learning application has three menu categories: material, search and bookmarks [6].

This study conducted two tests, system testing and user testing. The researchers employed the black-box testing system for system testing and a questionnaire based on a Likert scale for user testing. The respondents were 20 dentistry students. This research was conducted at Universitas Muhammadiyah Yogyakarta in December 2017.

In system testing, the functional software tests were carried out to obtain a series of input conditions following the functional requirements of a program. The State Transition Table test was designed to check the validity of transitions between states.

In user testing, several answer criteria were given to respondents using a Likert scale measurement to measure their attitudes, opinions and perceptions regarding social phenomena. Respondents were asked to use the information system as a whole and choose one choice from the answers in the questionnaire. There are five choices of answers given, ranging from strongly agree to strongly disagree. The quantitative data were changed based on the weighted scores of one, two, three, four and five. The division of categories and measurement scores on the Likert scale is presented in Table 1[7]..

Table 1. Likert Score Table

\begin{tabular}{ccc}
\hline No & Category & Score \\
\hline 1 & Strongly Agree & 5 \\
2 & Agree & 4 \\
3 & Quite Agree & 3 \\
4 & Disagree & 2 \\
5 & Strongly Disagree & 1 \\
\hline
\end{tabular}


The percentage of results was used to provide answers to the feasibility of the aspects studied. The maximum expected value is $100 \%$, and the minimum is $0 \%$.

The division of eligibility categories is portrayed in Table 2 .

Table 2. Application Eligibility Category

\begin{tabular}{lcc|}
\hline No & Category & Percentage \\
\hline 1 & Very Worthy & $81 \%-100 \%$ \\
2 & Worthy & $61 \%-80 \%$ \\
3 & Sufficiently Worthy & $41 \%-60 \%$ \\
4 & Unworthy & $21 \%-40 \%$ \\
5 & Very Unworthy & $<20 \%$ \\
\hline \multicolumn{3}{|c|}{ Score T x Pn } \\
T & $=$ The total number of respondents who voted \\
Pn & $=$ Choice of Likert score numbers \\
\hline \multicolumn{3}{|}{ Eligibility Index = Total Score / Y x 100 } \\
$\mathbf{Y}$ & $=$ Likert highest score x number of respondents \\
\hline
\end{tabular}

\section{Results}

The test method using black-box testing, namely through the State Transition Table method, is demonstrated in system testing results in Table 3 [8] [9].

Table 3. System Testing Results

\begin{tabular}{|c|c|c|c|}
\hline No & Input & Expected Output & $\begin{array}{c}\text { Statu } \\
\text { s }\end{array}$ \\
\hline 1. & $\begin{array}{l}\text { Displaying the entire list of dental } \\
\text { anatomy on the homepage }\end{array}$ & $\begin{array}{l}\text { The system will display the } \\
\text { entire list of dental anatomy on } \\
\text { the homepage. }\end{array}$ & Valid \\
\hline 2. & $\begin{array}{l}\text { Displaying an error message of "Failed to } \\
\text { retrieve data, Check your connection!" if } \\
\text { the smartphone is not connected to the } \\
\text { internet network }\end{array}$ & $\begin{array}{l}\text { The system will display the } \\
\text { message of "Failed to retrieve } \\
\text { data, Check your connection!" }\end{array}$ & Valid \\
\hline 3. & $\begin{array}{l}\text { Displaying the name, scientific name, and } \\
\text { image by selecting one of the dental } \\
\text { anatomy lists on the homepage }\end{array}$ & $\begin{array}{l}\text { The system will display the } \\
\text { name, scientific name, and } \\
\text { image. }\end{array}$ & Valid \\
\hline 4. & $\begin{array}{l}\text { Displaying the "Bookmark successful" } \\
\text { message when clicking the bookmark } \\
\text { button }\end{array}$ & $\begin{array}{l}\text { The system will display the } \\
\text { "Bookmark successful" } \\
\text { message. }\end{array}$ & Valid \\
\hline 5. & $\begin{array}{l}\text { Displaying a list of dental anatomy when } \\
\text { the user enters a keyword in the search for } \\
\text { scientific names and names }\end{array}$ & $\begin{array}{l}\text { The system will display a list } \\
\text { of dental anatomy in the search } \\
\text { for scientific names and names. }\end{array}$ & Valid \\
\hline 6. & $\begin{array}{l}\text { Displaying an error message of "Data not } \\
\text { found" if the keywords do not match the } \\
\text { data in the application }\end{array}$ & $\begin{array}{l}\text { The system displays an error } \\
\text { message of "Data not found". }\end{array}$ & Valid \\
\hline 7. & $\begin{array}{l}\text { Displaying bookmarked data by clicking } \\
\text { on the bookmark on the homepage }\end{array}$ & $\begin{array}{l}\text { The system will display the } \\
\text { bookmarked data. }\end{array}$ & Valid \\
\hline 8. & $\begin{array}{l}\text { Displaying the "delete" message when } \\
\text { clicking and holding one of the dental }\end{array}$ & $\begin{array}{l}\text { The system will display the } \\
\text { "delete" message. }\end{array}$ & Valid \\
\hline
\end{tabular}




\begin{tabular}{rlll}
\hline No & \multicolumn{1}{c}{ Input } & \multicolumn{1}{c}{ Expected Output } & \multicolumn{1}{c}{$\begin{array}{c}\text { Statu } \\
\text { S }\end{array}$} \\
\hline $\begin{array}{l}\text { anatomy lists on the bookmark page } \\
\text { 9eleting existing data on the Bookmark } \\
\text { page when clicking the "delete" message }\end{array}$ & $\begin{array}{l}\text { The system will delete the data } \\
\text { on the Bookmark page. }\end{array}$ & Valid \\
10. $\begin{array}{l}\text { Displaying the message and the "Delete } \\
\text { The system will display the } \\
\text { message and the "Delete All } \\
\text { delete button }\end{array}$ & Valid \\
11. $\begin{array}{l}\text { Erasing all data on the Bookmark page } \\
\text { when selecting the "Yes" option }\end{array}$ & $\begin{array}{l}\text { Bookmarks" option. } \\
\text { The system will delete all data } \\
\text { on the Bookmark page. }\end{array}$ & Valid \\
\hline
\end{tabular}

User testing was calculated based on the Likert scale formula, which was the calculation of the feasibility of question number one in the questionnaire:

\section{Score T x Pn}

$\mathbf{T}=$ The total number of respondents who voted

$\mathbf{P n}=$ Choice of Likert score numbers

- Respondents who answered Strongly Agree (5)

$$
13 \times 5=65
$$

- Respondents who answered Agree (4)

$5 \times 4=20$

- Respondents who answered Quiet Agree (3)

$2 \times 3=6$

- Respondents who answered Disagree (2)

$0 \times 2=0$

- Respondents who answered Strongly Disagree (1)

$0 \times 1=0$

Total Score $=65+20+6$

$$
=91
$$

\section{Eligibility Index = Total Score $/$ Y x 100}

$\mathbf{Y}=$ Likert highest score $\mathrm{x}$ number of respondents

$$
\begin{aligned}
\text { Eligibility Index } & =91 /(5 \times 20) \times 100 \\
& =91 / 100 \times 100 \\
& =0.91 \times 100 \\
& =91
\end{aligned}
$$

Therefore, the percentage of application eligibility was obtained with an index of $91 \%$, belonging to the "very worthy" category for question number one. The results of the application feasibility test are presented in Table 4. 
Table 4. Application Eligibility Testing

\begin{tabular}{|c|c|c|c|c|c|c|c|c|}
\hline \multirow[t]{3}{*}{ No } & Question & \multicolumn{5}{|c|}{ Answer } & \multirow{3}{*}{$\underset{\%}{\text { Eligibility }}$} & \multirow[t]{3}{*}{ Category } \\
\hline & Score & 5 & 4 & 3 & 2 & 1 & & \\
\hline & Answer & SA & $\mathbf{A}$ & QA & D & SD & & \\
\hline 1 & Is the application easy to use by users? & 13 & 5 & 2 & 0 & 0 & $91 \%$ & $\begin{array}{c}\text { Very } \\
\text { Worthy }\end{array}$ \\
\hline 2 & $\begin{array}{l}\text { Can the information displayed in the } \\
\text { application be captured easily and } \\
\text { clearly? }\end{array}$ & 12 & 6 & 2 & 0 & 0 & $90 \%$ & $\begin{array}{l}\text { Very } \\
\text { Worthy }\end{array}$ \\
\hline 3 & $\begin{array}{l}\text { Does the application have a user- } \\
\text { friendly appearance? }\end{array}$ & 8 & 8 & 4 & 0 & 0 & $84 \%$ & $\begin{array}{l}\text { Very } \\
\text { Worthy }\end{array}$ \\
\hline 4 & $\begin{array}{l}\text { Is the search application feature } \\
\text { beneficial for users? }\end{array}$ & 10 & 9 & 1 & 0 & 0 & $89 \%$ & $\begin{array}{l}\text { Very } \\
\text { Worthy }\end{array}$ \\
\hline 5 & $\begin{array}{l}\text { Does the bookmark feature of the } \\
\text { application help users? }\end{array}$ & 8 & 8 & 3 & 1 & 0 & $82 \%$ & $\begin{array}{l}\text { Very } \\
\text { Worthy }\end{array}$ \\
\hline 6 & $\begin{array}{l}\text { Is the teeth anatomy learning } \\
\text { application beneficial? }\end{array}$ & 11 & 5 & 3 & 1 & 0 & $86 \%$ & $\begin{array}{c}\text { Very } \\
\text { Worthy }\end{array}$ \\
\hline
\end{tabular}

It can be concluded that the Android-based teeth anatomy learning application using Mayer's multimedia learning principles can help users learn dental anatomy more easily[10]. Data processing using a questionnaire obtained an average percentage of $87 \%$. Thus, with these results, the application built by the author falls into a very worthy category[11].

\section{Conclusions}

The following conclusions were drawn based on the research and activities carried out during the development of the Android-based dental anatomy learning application.

1. This Android-based teeth anatomy learning application is a tool to learn dental anatomy.

2. The Android-based teeth anatomy learning application eases to learn dental anatomy.

\section{References}

[1] E. Sloane, "Anatomi dan Fisiologi Untuk Pemula [Anatomy and Physiology for Beginners]," Penerbit Buku Kedokt. EGC Jkt., 2004.

[2] R. E. Mayer, "Multimedia learning," in Psychology of learning and motivation, vol. 41, Elsevier, 2002, pp. 85-139.

[3] T. Purwanti, "Aplikasi pembelajaran sistem peredaran darah manusia berbasis augmented reality android [Learning application for human circulatory system based on android augmented reality]," 2015.

[4] S. H. M. Ali, "Program Bantu Pengenalan Anatomi Tubuh Manusia Dengan Metode Window Clipping Berbasis Android (Studi Kasus Tulang Manusia) [Human Body Anatomy Recognition Program With Android-Based Window Clipping Method (Human Bone Case Study)]," 2017.

[5] H. O. L. Wijaya, "Aplikasi Mobile Learning Anatomi Tubuh Manusia Berbasis Android Studi Kasus (Sekolah Dasar Negeri 58 Kota Lubuklinggau) [Mobile Learning Application of Human Body Anatomy Based on Android Case Studies (58 Public Elementary Schools in Lubuklinggau City)],” J. Teknol. Inf. Mura, Vol. 7, No. 1, 2015.

[6] A. I. Satria, L. Andrawina, And H. D. Anggana, "Perancangan Sistem Informasi Manajemen Pemesanan Tiket Pesawat Pada Travel Agent Wiro Karya Berbasis Web Dengan Metode Waterfall [Design Of Management Information System For Aircraft Ticket Ordering On Web-Based Travel Agent Wiro With Waterfall Method]," p. 10, 2020.

[7] M. Mawardi, "Rambu-rambu Penyusunan Skala Sikap Model Likert untuk Mengukur Sikap Siswa [Signs for Developing a Likert Model Attitude Scale to Measure Student Attitudes]," Sch. J. Pendidik. Dan Kebud., vol. 9, no. 3, pp. 292-304, 2019.

[8] R. Pressman, “Software Engineering: a practitioner's approach McGraw-Hill, new York, 68,” 2010.

[9] T. Hidayat and M. Muttaqin, "Pengujian Sistem Informasi Pendaftaran dan Pembayaran Wisuda Online menggunakan Black Box Testing dengan Metode Equivalence Partitioning dan Boundary Value Analysis [Testing of Online Graduation Registration and Payment Information Systems using Black Box Testing with Equivalence Partitioning Methods and Boundary Value Analysis]," vol. 6, p. 5, 2018.

[10] P. Dr, "Sugiyono, Metode Penelitian Kuantitatif Kualitatif dan R\&D [Sugiyono, Qualitative and Quantitative Research Methods and R \& D]," 2008.

[11] Y. Cheon and C. Chavez, "Creating Flutter Apps from Native Android Apps," p. 10. 